\title{
Physicochemical Meat Quality and Sensory Property of Holstein Steer Beef Produced by Different Fattening Periods
}

\author{
Soohyun Cho'*, Jongin Kim ${ }^{1,2}$, Sunmoon Kang ${ }^{1}$, Geunho Kang ${ }^{1}$, Pilnam Seong ${ }^{1}$, Kyungmi Park ${ }^{1}$, \\ Kwangsuk $\mathrm{Ki}^{1}$, Hyunsub Kim${ }^{1}$, CheonJei Kim ${ }^{1,2}$, and Beomyoung Park ${ }^{1}$ \\ ${ }^{1}$ Animal Products Research and Development Division, National Institute of Animal Science, Suwon 441-706, Korea \\ ${ }^{2}$ Department of Food Science and Biotechnology of Animal Resources, Konkuk University, Seoul 143-701, Korea
}

\begin{abstract}
This study was performed to investigate the physico-chemical properties of Holstein steer beef loin (M. longissimus dorsi) and top round (M. semimembranosus) from 18, 21 and 24-mon old. The loin and top round muscles from the 24-mon group had higher intramuscular fat content $(\%)$ than the other groups $(p<0.05)$; however, the protein content was not significantly different among the 3 groups $(p>0.05)$. With regard to meat color (CIE), the lightness ( $\left.\mathrm{L}^{*}\right)$, redness $\left(\mathrm{a}^{*}\right)$ and yellowness $\left(\mathrm{b}^{*}\right)$ values of the loin were significantly higher for the 21- and 24-mon groups, and those of the top round were significantly higher for the 21-mon group than the same cuts in the other groups. The Warner-Bratzler shear force was the lowest at 24 mon for both the loin and top round muscles $(3.69 \mathrm{~kg})$; however, the water holding capacity was significantly higher for loin muscles from the 21 -mon group $(54.53 \%, p<0.05)$. The loin muscles from the 24 -mon group contained significantly higher levels of monounsaturated fatty acid and significantly lower levels of saturated fatty acid than those in the other groups $(p<0.05)$. The tenderness, juiciness, flavor-likeness and the overall-likeness scores were significantly higher for beef from the 21- and 24-mon groups than that from the 18-mon group. The results of this study indicate that both the slaughtering age and muscle type significantly affect meat quality. Therefore, fattening the beef for more than 4 mon during the late fattening stage would be advantageous for the meat quality of Holstein steers.
\end{abstract}

Key words: fattening period, Holstein steer, meat quality, fatty acids, sensory property

\section{Introduction}

The Holstein cattle breed was imported into Korea in 1903 , and it is the premier dairy breed with a high potential for milk production. In 2011, approximately 79,529 heads of Holstein beef cattle were slaughtered in Korea (Holstein steers, 72,901; Holstein bulls, 6628) for meat production (KAPE, 2011). Few data are available on Holstein cattle, despite the fact that this breed provides a considerable proportion of the beef consumed throughout the world.

Investigations of the meat quality of different breeds have mostly concentrated on age, length of the fattening period, and the weight of the animals. Castration has been proposed as a means of enhancing meat quality, along with improvements to feeding technology and slaughtering age. Castration of bulls increases carcass backfat

*Corresponding author: Soohyun Cho, Animal Products Research and Development Division, National Institute of Animal Science, Suwon 441-706, Korea. Tel: 82-31-290-1703 Fax: 82-31-2901697, E-mail: shc0915@korea.kr
(Field, 1971; Knight et al., 1999), intramuscular fat content (Knight et al., 1999; Purchas et al., 2002), and tenderness (Morgan et al., 1993; Purchas et al., 2002), and it reduces the incidence of high ultimate meat $\mathrm{pH}$ (Knight et al., 1999; Morgan et al., 1993). Additionally, castration reduces aggressive and sexual behavior, improves animal handling, and reduces carcass bruising (Katz, 2007). The differences in performance between intact bulls and castrates mainly manifest after puberty due to the increased production of anabolic hormones by the testes (Adams et al., 1996), which is attained at 6-9 mon of age and 250$380 \mathrm{~kg}$ of body weight in Holstein bulls (Lunstra et al., 1978). The yield grade (YG) of Holstein bulls (YG A, 23.3\%) is higher than that of Holstein steers (YG A, $1.3 \%)$. The meat from Holstein is marketed with a low price due to its low quality and palatability. Korean consumers prefer highly marbled beef, especially from Hanwoo, and the frequency of beef with quality grade (QG) 1 is $62.4 \%$. However, the frequency of higher than QG 1 for Holstein bulls and steers is only $15.5 \%$. In 2011, $94.5 \%$ of the Holstein bulls had QG 3, whereas $45.2 \%$ of the Holstein steers had QG 3, 40.9\% had QG 2, 10.4\% 
had QG 1, 2.8\% had QG $1^{+}$, and $0.4 \%$ had QG $1^{++}$when they were slaughtered at 20-21 mon (KAPE, 2011). Although the overall beef consumption in 2011 increased by $38.4 \%$ to 505 metric tons (MT), beef production from Holstein bulls and steers in 2011 decreased by $16 \%$ to 26 MT when compared to that in 2008 (MIFAFF, 2012). In Japan, a Holstein cross-breed was produced to improve the meat quality of Japanese black cattle, and they were fed with grass forage or total mixed ratio for highly marbled beef (Cho et al., 2005). The demand for a longer feeding period was increased; however, very few studies have characterized carcass, muscle, and meat quality characteristics according to the different feeding periods for the Holstein breed.

The objective of this study was to investigate the physico-chemical properties of Holstein steer beef loin $(M$. longissimus dorsi) and top round (M. semimembranosus) from 18, 21, and 24-mon-old after they were fattened for different periods.

\section{Materials and Methods}

\section{Sample preparation}

Eighteen Holstein steers $(18,21$, and 24 mon old; live weight, $350-500 \mathrm{~kg}$ ) were finished at the Yukpumjung farm and divided into 3 groups (6 heads/group) for slaughter at Yukpumjung Co. Ltd. in Korea. They were fed at the growth stage for $8 \mathrm{mon}$, the early fattening stage for 7 mon, and then the late fattening periods were divided into 1, 4 and 7 mon. At the end of each fattening periods (18, 21 and 24 mon-old), the animals were slaughtered and processed.

The right side of each carcass was hung by the Achilles tendon and chilled at $4^{\circ} \mathrm{C}$. Approximately $48 \mathrm{~h}$ post-mortem, the quality grade was assigned from 5 possible values $\left(1^{++}, 1^{+}, 1,2,3\right)$ based on the marbling score, lean meat color, fat color, firmness, texture of lean meat, and maturity of the exposed longissimus dorsi (LD) muscle at the thirteenth rib interface (National Livestock Cooperatives Federation, 1998). The right side of the carcass was deboned and trimmed to domestic fabrication. The loin (M. longissimus lumborum, LD) and top round (M. semimembranosus, SM) were separated, vacuum-packaged, and stored at $2^{\circ} \mathrm{C}$ or 3 days for analysis of meat quality. For fatty acid analysis, each sample, consisting of approximately $100 \mathrm{~g}$ of tissue, was vacuum-packaged and stored at $20^{\circ} \mathrm{C}$ until the analysis was conducted (approximately 2 wk post-mortem).

\section{Chemical and meat quality analysis procedures}

Protein, fat, moisture, and collagen content were analyzed using the Food Scan ${ }^{\mathrm{TM}}$ Lab 78810 (Foss Tecator Co., Ltd., Denmark), according to the method of the Association of Official Analytical Chemists (AOAC, 2006). Water-holding capacity (WHC) was measured using the method of Ryoichi et al. (1993). Color values on a freshly cut surface of the Warner-Bratzler shear force (WBSF) block were measured using a CR-301 chroma meter (Minolta Co., Japan) for CIE standard lightness $\left(\mathrm{L}^{*}\right)$, redness $\left(\mathrm{a}^{*}\right)$, and yellowness $\left(\mathrm{b}^{*}\right)$ after a $30 \mathrm{~min}$ blooming at $2^{\circ} \mathrm{C}$ (Commision Internationale de Leclairage, 1986). The cooking loss (\%) was calculated as the percent of weight change during cooking for the WBSF measurement. For cooking loss determination, the samples were freshly cut into blocks $(50 \times 50 \times 25 \mathrm{~mm})$ and weighed (initial weight). Individual meat blocks were placed in a water-bath at $80^{\circ} \mathrm{C}$ for $40 \mathrm{~min}$. The samples were removed from the water-bath, cooled in cold water, and weighed. The cooking loss was expressed as a percentage of the initial sample weight (Honikel, 1998). WBSF was measured on cooked steaks ( $25 \mathrm{~mm}$ thick) according to the method of Wheeler et al. (2000) using an Instron Universal Testing Machine (Model 5543, UK). Total lipids of beef samples were extracted by using chloroform-methanol $(2: 1, \mathrm{v} / \mathrm{v})$ according to the procedure of Folch et al. (1957). An aliquot of total lipid extract was methylated as described by Morrison and Smith (1964). Fatty acid methyl esters were analyzed by a gas chromatograph (Star 3600, Varian technologies, USA) fitted with a fused silica capillary column, omegawas $205(30 \mathrm{~m} \times 0.32 \mathrm{~mm}$ i.d., $0.25 \mu \mathrm{m}$ film thickness). The injection port was at $250^{\circ} \mathrm{C}$ and the detector was maintained at $300^{\circ} \mathrm{C}$. Results were expressed as percentages based on the total peak area.

\section{Sensory evaluation}

For Korean roast thin-slice-style cooking, the beef strips were thawed at $4^{\circ} \mathrm{C}$ in the refrigerator. Individual strips were cooked by placing them on a tin plate equipped with a water jacket (at approximately $245-255^{\circ} \mathrm{C}$ ). Strips were turned at the first pooling of liquid on the surface of the sample or at the start of shrinkage. The cooked strips were immediately served to 7 trained sensory panelists for evaluation. The panelists were asked to score the samples for tenderness, juiciness, flavor, and overall liking. Scoring was performed on a single sheet using four 100 $\mathrm{mm}$ lines from 0 to 100 , with $20 \mathrm{~mm}$ gradients marked. Tenderness ranged from very tough (0) to very tender (100); juiciness ranged from very dry (0) to very juicy (100). 
Flavor ranged from extreme dislike $(0)$ to extreme like (100); overall liking ranged from extreme dislike $(0)$ to extreme like (100).

\section{Statistical analysis}

Each animal within the same slaughtering age group was treated as a replicate. Data were analyzed by the Student-Newman-Keuls' multiple comparison using the General Linear Model Procedure of the SAS program (2005). The significance level was set at $p<0.05$, and a value of $0.05<p<0.10$ was considered a statistical trend.

\section{Results and Discussion}

\section{Chemical composition}

The moisture, protein, fat, and collagen contents of the loin and top round beef from Holstein steers are shown in Table 1. For loin, the moisture content was lower in the $21-(67.17 \%)$ and 24 -mon groups $(66.38 \%)$ than that in the 18-mon group $(70.59 \%)(p<0.05)$. Fat content of loin was significantly higher for $21-(8.19 \%)$ and 24 -mon-old $(9.62 \%)$ steers than that for 18 -mon-old steers $(5.49 \%)$ $(p<0.05)$. For top round, fat content of the 24-mon group was highest $(4.31 \%)$; there were no significant differences in the protein content between the 3 slaughtering ages $(p>0.05)$. European cattle breeding and husbandry efforts have focused on the efficient production of lean meat, while the beef industry in the United States has focused on intramuscular fat as an important factor of meat quality (Gotoh et al., 2009). Visible intramuscular fat (IMF) or marbling is an important meat characteristic which is appreciated by the consumer because of its positive effects on taste, juiciness, and tenderness (Platter et al., 2005). The development of marbling is not com-

Table 1. Chemical compositions (\%) of loin and top round muscles of Holstein steer beef by different slaughtering ages

\begin{tabular}{ccccc}
\hline \hline $\begin{array}{c}\text { Fattening } \\
\text { time (mon) }\end{array}$ & $\begin{array}{c}\text { Moisture } \\
(\%)\end{array}$ & $\begin{array}{c}\text { Protein } \\
(\%)\end{array}$ & $\begin{array}{c}\text { Fat } \\
(\%)\end{array}$ & $\begin{array}{c}\text { Collagen } \\
(\%)\end{array}$ \\
\hline Loin & & & & \\
18 & $70.59 \pm 0.28^{\mathrm{a}}$ & $20.29 \pm 0.21$ & $5.49 \pm 0.40^{\mathrm{b}}$ & $1.69 \pm 0.03^{\mathrm{b}}$ \\
21 & $67.17 \pm 0.52^{\mathrm{b}}$ & $20.65 \pm 0.10$ & $8.19 \pm 0.57^{\mathrm{a}}$ & $1.78 \pm 0.05^{\mathrm{b}}$ \\
24 & $66.38 \pm 0.86^{\mathrm{b}}$ & $20.15 \pm 0.27$ & $9.62 \pm 1.08^{\mathrm{a}}$ & $1.93 \pm 0.06^{\mathrm{a}}$ \\
\hline Top round & & & & \\
18 & $73.07 \pm 0.19^{\mathrm{a}}$ & $20.82 \pm 0.16$ & $2.79 \pm 0.14^{\mathrm{b}}$ & $1.68 \pm 0.03^{\mathrm{ab}}$ \\
21 & $70.86 \pm 0.29^{\mathrm{c}}$ & $21.09 \pm 0.34$ & $2.96 \pm 0.16^{\mathrm{b}}$ & $1.63 \pm 0.05^{\mathrm{b}}$ \\
24 & $71.90 \pm 0.27^{\mathrm{b}}$ & $21.07 \pm 0.14$ & $4.31 \pm 0.52^{\mathrm{a}}$ & $2.19 \pm 0.03^{\mathrm{a}}$ \\
\hline *Mean \pm SE & & & \\
a-c Means in the same column within the same category with dif- \\
ferent letters are significantly different $(p<0.05)$.
\end{tabular}

pletely independent from other fat deposits in the body, and fat distribution between different deposits in the carcass varies according to the breed, sex, and nutrition (Pethick et al., 2004; Robelin, 1986). In former studies, it has been shown that IMF develops in different breeds continuously during growth but with varying intensity, leading to different marbling scores at slaughter (Bruns et al., 2004). Kang et al. (2005) reported that Holstein steers contained high intramuscular fat when they were fed with total mixed ratio containing brewers dried grain for 6-23 mon. On the other hand, there were no significant differences in the moisture and fat content in the loin of Holstein steer beef when slaughtered at 17-19 mon (Kim et al., 1996). It was reported that castration improved the meat quality of Hanwoo, with increased IMF when compared to Hanwoo bulls (Kwak et al., 1995). Some studies on dry beef cows (Cranwell et al., 1996) have found that high-energy finishing diets improved the color characteristics, increased marbling and IMF, reduced the shear force value, and improved the sensory-panel tenderness scores. Therefore, Holstein steer beef may have increased marbling when fattened and slaughtered at ages beyond 21 mon. Total collagen content was also significantly higher in the loin $(1.93 \%)$ and top round $(2.19 \%)$ from Holstein steer beef raised for 24 mon $(p<0.05)$ (Table 1$)$. Kim et al. (1996) reported that fat and collagen content of loin were not significantly different between the 17-, 18-, and 19-mon-old Holstein steer beef; however, there were significant differences in these values between 20- and 22mon-old animals. Boccard et al. (1979) also reported that collagen content began to significantly increase from 20 mon of age.

\section{Meat Quality}

Regarding meat color, $\mathrm{L}^{*}, \mathrm{a}^{*}$, and $\mathrm{b}^{*}$ values of loin were significantly higher in the 21- and 24-mon groups, and those of top round were significant higher in the 21mon groups, than that of the other groups $(p<0.05)$ (Table $2)$. Sung et al. (1996) reported that the $L^{*}$ values and heme pigment content were not significantly different between animals slaughtered at 17, 18 and 19 mon of age, but the $a^{*}$ and $b^{*}$ values increased as the slaughtering age increased from 17 to 19 mon. Meat color (a*) values significantly increased $(p<0.05)$ as the age increased from 3 to 9 to 12 to 15 mon in young Qinchuan cattle of China (Li et al., 2011).

There were no significant differences in the cooking loss $(\%)$ between the different slaughtering ages or between the 2 muscles $(p>0.05)$. Loin and top round muscles from 
Table 2. Meat color, cooking loss $(\%)$, sarcomere length $(\mu \mathrm{m})$, Warner-Bratzler shear force (WBS), and water holding capacity (WHC) of loin and top round muscles of Holstein steer beef by different slaughtering ages

\begin{tabular}{|c|c|c|c|c|c|c|c|}
\hline \multirow{2}{*}{$\begin{array}{l}\text { Fattening time } \\
\qquad \text { (mon) }\end{array}$} & \multicolumn{3}{|c|}{ Meat color } & \multirow{2}{*}{$\begin{array}{c}\text { Cooking loss } \\
(\%)\end{array}$} & \multirow{2}{*}{$\begin{array}{l}\text { Sarcomere } \\
\text { length }(\mu \mathrm{m})\end{array}$} & \multirow{2}{*}{$\begin{array}{c}\text { WBS } \\
\left(\mathrm{kg} / 0.5 \mathrm{inch}^{2}\right)\end{array}$} & \multirow{2}{*}{$\begin{array}{l}\text { WHC } \\
(\%)\end{array}$} \\
\hline & $\mathrm{L}$ & $\mathrm{a}$ & $\mathrm{b}$ & & & & \\
\hline \multicolumn{8}{|l|}{ Loin } \\
\hline 18 & $28.04 \pm 0.38^{b}$ & $13.24 \pm 0.21^{\mathrm{b}}$ & $4.67 \pm 0.11^{\mathrm{b}}$ & $25.65 \pm 0.75$ & $2.56 \pm 0.08$ & $3.95 \pm 0.14^{\mathrm{a}}$ & $56.86 \pm 0.89^{b}$ \\
\hline 21 & $31.06 \pm 0.61^{\mathrm{a}}$ & $14.97 \pm 0.62^{\mathrm{a}}$ & $5.68 \pm 0.24^{\mathrm{a}}$ & $25.32 \pm 0.94$ & $2.51 \pm 0.07$ & $3.89 \pm 0.12^{\mathrm{a}}$ & $59.53 \pm 0.78^{\mathrm{a}}$ \\
\hline 24 & $31.60 \pm 0.54^{\mathrm{a}}$ & $15.46 \pm 0.47^{\mathrm{a}}$ & $5.90 \pm 0.22^{\mathrm{a}}$ & $25.32 \pm 0.94$ & $2.45 \pm 0.06$ & $3.69 \pm 0.19^{b}$ & $54.44 \pm 0.66^{\mathrm{c}}$ \\
\hline \multicolumn{8}{|l|}{ Top round } \\
\hline 18 & $35.31 \pm 0.85^{\mathrm{b}}$ & $19.20 \pm 0.53^{b}$ & $7.85 \pm 0.34^{\mathrm{b}}$ & $33.03 \pm 0.54$ & $2.38 \pm 0.03^{\mathrm{a}}$ & $6.00 \pm 0.17^{\mathrm{a}}$ & $53.63 \pm 0.64^{\mathrm{ab}}$ \\
\hline 21 & $38.85 \pm 0.77^{\mathrm{a}}$ & $23.00 \pm 0.39^{\mathrm{a}}$ & $11.90 \pm 0.25^{\mathrm{a}}$ & $31.94 \pm 1.53$ & $2.24 \pm 0.03^{\mathrm{b}}$ & $4.45 \pm 0.17^{\mathrm{b}}$ & $54.93 \pm 0.86^{\mathrm{a}}$ \\
\hline 24 & $34.69 \pm 1.06^{\mathrm{b}}$ & $19.53 \pm 0.62^{b}$ & $7.88 \pm 0.38^{\mathrm{b}}$ & $32.63 \pm 0.39$ & $2.22 \pm 0.07^{\mathrm{b}}$ & $4.59 \pm 0.38^{\mathrm{b}}$ & $52.26 \pm 0.66^{\mathrm{b}}$ \\
\hline
\end{tabular}

*Mean \pm SE

${ }^{a-c}$ Means in the same column within the same category with different letters are significantly different $(p<0.05)$.

the 24-mon group had lower WBSF $(3.69 \mathrm{~kg}$ and $4.59 \mathrm{~kg}$, respectively) values than that from the 18 -mon group (3.95 kg and $6.00 \mathrm{~kg}$, respectively) $(p<0.05)$. There were no significant differences in the sarcomere length of the loin muscles between the different ages $(p>0.05)$; however, the sarcomere length values of the top round muscles were significantly longer in the 18-mon group (2.68 $\mu \mathrm{m})$ than that in the 21- $(2.24 \mu \mathrm{m})$ and 24-mon groups $(2.22 \mu \mathrm{m})(p<0.05)$ (Table 2$)$.

Color is the first quality attribute that influences a consumer's purchasing intent (Risvik, 1994), whilst toughness is the attribute that will determine whether a consumer will re-purchase the product. From this investigation,

Table 3. Fatty acid compositions (\%) of loin muscles of Holstein steer beef by different slaughtering ages

\begin{tabular}{lccc}
\hline \multirow{2}{*}{ Fatty acids } & \multicolumn{3}{c}{ Slaughtering age (mon) } \\
\cline { 2 - 4 } & 18 & 21 & 24 \\
\hline C14:0 & $3.34 \pm 0.12$ & $3.23 \pm 0.20$ & $3.20 \pm 0.24$ \\
C16:0 & $31.90 \pm 0.58$ & $30.85 \pm 0.70$ & $30.86 \pm 0.68$ \\
C16:1n7 & $3.23 \pm 0.19$ & $2.67 \pm 0.35$ & $3.27 \pm 0.19$ \\
C18:0 & $15.70 \pm 0.67$ & $16.50 \pm 0.72$ & $13.81 \pm 0.88$ \\
C18:1n7 & $0.25 \pm 0.04$ & $0.20 \pm 0.02$ & $0.31 \pm 0.02$ \\
C18:1n9 & $43.10 \pm 1.15$ & $44.05 \pm 1.17$ & $46.24 \pm 0.92$ \\
C18:2n6 & $2.18 \pm 0.14$ & $2.29 \pm 0.19$ & $2.09 \pm 0.18$ \\
C18:3n3 & $0.04 \pm 0.01$ & $0.04 \pm 0.01$ & $0.04 \pm 0.00$ \\
C18:3n6 & $0.05 \pm 0.00$ & $0.04 \pm 0.00$ & $0.04 \pm 0.01$ \\
C20:1n9 & $0.02 \pm 0.00$ & $0.02 \pm 0.00$ & $0.05 \pm 0.01$ \\
C20:4n6 & $0.18 \pm 0.06$ & $0.14 \pm 0.02$ & $0.09 \pm 0.02$ \\
MUFA/SFA & $0.92 \pm 0.05$ & $0.93 \pm 0.05$ & $1.05 \pm 0.05$ \\
PUFA/SFA & $0.05 \pm 0.00$ & $0.05 \pm 0.01$ & $0.05 \pm 0.00$ \\
SFA & $50.94 \pm 1.22^{\mathrm{a}}$ & $50.57 \pm 1.39^{\mathrm{a}}$ & $47.87 \pm 1.06^{\mathrm{b}}$ \\
MUFA & $46.61 \pm 1.31^{\mathrm{b}}$ & $46.93 \pm 1.21^{\mathrm{b}}$ & $49.87 \pm 0.97^{\mathrm{a}}$ \\
PUFA & $2.46 \pm 0.20$ & $2.51 \pm 0.20$ & $2.26 \pm 0.19$ \\
\hline
\end{tabular}

\footnotetext{
*Mean \pm SE

${ }^{\mathrm{a}-\mathrm{b}}$ Means in the same row within the same category with different letters are significantly different $(p<0.05)$.
}

meat from cattle fattened for 21-24 mon should thus be more readily purchased than that from the 18 -mon old Holstein steer beef cattle. Tenderness is one of the most important organoleptic characteristics by which consumers judge meat quality. Previous authors have shown that beef from concentrate-fed animals had lower shear force than the beef from animals finished on forages (Bowling et al., 1977; Davis et al., 1981). However, WHC was significantly higher for the loin $(59.53 \%)$ and top round $(54.93 \%)$ muscles from 21 -mon-old cattle than that for the other age groups $(p<0.05)$ (Table 2).

\section{Fatty acid composition}

The fatty acid compositions (\%) of $m$. longissimus dorsi and $m$. semimembranosus after different fattening

Table 4. Fatty acid compositions (\%) of top round muscles from Holstein steer beef by different slaughtering ages

\begin{tabular}{lrrr}
\hline \hline \multirow{3}{*}{ Fatty acids } & \multicolumn{3}{c}{ Slaughtering age (mon) } \\
\cline { 2 - 4 } & \multicolumn{1}{c}{18} & \multicolumn{1}{c}{21} & \multicolumn{1}{c}{24} \\
\hline C14:0 & $2.70 \pm 0.14$ & $2.48 \pm 0.09$ & $2.57 \pm 0.24$ \\
C16:0 & $28.29 \pm 0.35$ & $28.31 \pm 0.73$ & $28.75 \pm 0.56$ \\
C16:1n7 & $4.81 \pm 0.43$ & $2.68 \pm 0.81$ & $3.90 \pm 0.64$ \\
C18:0 & $11.48 \pm 0.45$ & $12.92 \pm 0.98$ & $10.79 \pm 0.82$ \\
C18:1n7 & $0.44 \pm 0.06$ & $0.34 \pm 0.08$ & $0.48 \pm 0.08$ \\
C18:1n9 & $48.92 \pm 0.47$ & $50.16 \pm 0.47$ & $49.97 \pm 0.81$ \\
C18:2n6 & $2.65 \pm 0.22$ & $2.63 \pm 0.20$ & $2.90 \pm 0.47$ \\
C18:3n3 & $0.04 \pm 0.01$ & $0.04 \pm 0.01$ & $0.05 \pm 0.01$ \\
C18:3n6 & $0.03 \pm 0.00$ & $0.04 \pm 0.01$ & $0.04 \pm 0.00$ \\
C20:1n9 & $0.05 \pm 0.00$ & $0.04 \pm 0.00$ & $0.07 \pm 0.01$ \\
C20:4n6 & $0.58 \pm 0.16$ & $0.38 \pm 0.08$ & $0.50 \pm 0.17$ \\
MUFA/SFA & $1.28 \pm 0.02$ & $1.23 \pm 0.06$ & $0.30 \pm 0.05$ \\
PUFA/SFA & $0.08 \pm 0.01$ & $0.07 \pm 0.01$ & $0.08 \pm 0.01$ \\
SFA & $42.47 \pm 0.53$ & $43.7 \pm 1.10$ & $42.11 \pm 0.89$ \\
MUFA & $54.22 \pm 0.39$ & $53.22 \pm 0.89$ & $54.41 \pm 0.99$ \\
PUFA & $3.31 \pm 0.36$ & $3.08 \pm 0.27$ & $3.48 \pm 0.64$ \\
\hline
\end{tabular}

*Mean \pm SE 
periods on a concentrate diet are shown in Tables 3 and 4 . As shown in Table 3, there was a numerical increase from 18 to 24 mon for $\mathrm{C} 18: \ln 9$ and $\mathrm{C} 20: 1 \mathrm{n} 9$; whereas, there was a decrease for $\mathrm{C} 14: 0, \mathrm{C} 20: 4 \mathrm{n} 6(p>0.05)$. The summation of saturated fatty acids (C14:0, C16:0, C18:0) was significantly decreased, whereas the summation of monounsaturated fatty acids (MUFA) (C16:1n7, C18:1n7, $\mathrm{C} 18: \ln 9, \mathrm{C} 20: \ln 9)$ was significantly increased as the fattening period increased $(p<0.05)$. The sum of the polyunsaturated fatty acid did not differ $(p>0.05)$ between the different fattening periods. The fatty acid $\mathrm{C} 18: 1 \mathrm{n} 9$ contributed to the overall increase of monounsaturated fatty acids by increasing from 18 to 24 mon. The fatty acid composition of dietary fats is of great importance in human nutrition and health. Numerous studies (Turek et al., 1996; Zhang et al., 1999) have demonstrated that dietary fatty acids with different degrees of saturation exert different effects on human health. Additionally, the degree of saturation of the fatty acids influences meat flavor (Purchas et al., 1979) and the consistency of adipose tissues (Bozzolo et al., 1990). Increased unsaturation results in greater flavor changes in ruminants, including beef, than that in pork (Melton, 1990). Breed-, age-, and sexrelated differences in the fatty acid composition of beeftype cattle have been widely demonstrated (Huerta-Leidenz et al., 1996; Perry et al., 1998). There were 3 major factors that influenced the fatty acid composition of beef: age of the animal, breed, and diet. Previous studies have reported the effects of different linseed forms and concentrations on performance and fatty acid composition of muscle and adipose tissue in beef cattle (Raes et al., 2004; Scollan et al., 2001). The fatty acid composition of Hanwoo (20-24 mon old) and Holstein steers (17-19 mon old) were compared at different slaughtering ages (Kim et

Table 5. Sensory evaluation of loin and top round muscles from Holstein steer beef by different slaughtering age

\begin{tabular}{ccccc}
\hline \hline $\begin{array}{c}\text { Slaughtering } \\
\text { age (mon) }\end{array}$ & Tenderness & Juiciness & $\begin{array}{c}\text { Flavor- } \\
\text { likeness }\end{array}$ & $\begin{array}{c}\text { Overall } \\
\text { likeness }\end{array}$ \\
\hline Loin & & & & \\
18 & $80.38 \pm 2.24^{\mathrm{b}}$ & $78.27 \pm 2.32^{\mathrm{b}}$ & $68.22 \pm 2.71^{\mathrm{b}}$ & $74.74 \pm 2.56^{\mathrm{b}}$ \\
21 & $87.30 \pm 2.09^{\mathrm{a}}$ & $84.97 \pm 1.71^{\mathrm{a}}$ & $75.43 \pm 2.42^{\mathrm{a}}$ & $83.49 \pm 2.05^{\mathrm{a}}$ \\
24 & $86.00 \pm 0.93^{\mathrm{a}}$ & $82.43 \pm 1.32^{\mathrm{ab}}$ & $80.31 \pm 1.55^{\mathrm{a}}$ & $82.63 \pm 1.28^{\mathrm{a}}$ \\
\hline Top round & & & & \\
18 & $57.37 \pm 2.62^{\mathrm{b}}$ & $63.07 \pm 2.85$ & $54.59 \pm 2.79$ & $54.60 \pm 2.44^{\mathrm{b}}$ \\
21 & $61.18 \pm 2.58^{\mathrm{b}}$ & $64.59 \pm 2.59$ & $58.02 \pm 2.69$ & $59.17 \pm 2.26^{\mathrm{ab}}$ \\
24 & $70.20 \pm 1.78^{\mathrm{a}}$ & $71.19 \pm 1.93$ & $63.63 \pm 2.67$ & $65.08 \pm 2.38^{\mathrm{a}}$ \\
\hline *Mean \pm SE & & & & \\
*-c Means in the same column within the same category with dif- \\
ferent letters are significantly different $(p<0.05)$.
\end{tabular}

al., 1996). The levels of unsaturated fatty acids (oleic acid, linoleic acid) increased and saturated fatty acids (palmitic acid, stearic acid) decreased for the Hanwoo steers, whereas the levels of saturated fatty acids (palmitic acid, stearic acid) increased and saturated fatty acids (linolenic acid) decreased for Holstein steers, as the slaughtering age increased.

\section{Sensory evaluation}

The results of the sensory evaluation are shown in Table 5. For the loin, the samples from the 21- and 24mon groups scored significantly higher for tenderness, flavor-likeness, and overall likeness than those from the 18-mon group $(p<0.05)$. Top round beef samples from the 24-mon group scored significantly higher for tenderness (68.20) and overall likeness (65.08) than those of the 18-mon group (57.37 and 54.60, respectively, $p<0.05$ ). Tenderness is one of the most important organoleptic characteristics by which consumers judge meat quality. Flavor is a general term used to encompass the taste, aroma, and umami of food when it is in the pressure- and heat-sensitive area of the mouth (Moody, 1983), and it is influenced by taste-active compounds, flavor enhancers, and aroma components, with over 880 such compounds presently identified in cooked beef (Macleod, 1994). Previous studies have shown that the IMF content is closely related to the tenderness, juiciness, and flavor of beef (Cho et al., 2005).

\section{Acknowledgements}

This study was supported by grants from National Institute of Animal Science, Rural Development of Administration, 2011.

\section{References}

1. Adams, T., Daley, C., Adam, B., and Sakurai, H. (1996) Testes function and feedlot performance of bulls actively immunized against gonadotropin-releasing hormone : Effect of age at immunization. J. Anim. Sci. 74, 950-954.

2. AOAC (2006) Official Methods of Analysis. 15th ed., Association of Official Analytical Chemists, Washington, D.C., 210-219.

3. Boccard, R. L., Naude, R. T., Crouse, D. E., Shim, M. C., Venter, H. J., and Rossow, F. I. (1979) The influence of age, sex and breed of cattle on their muscle characteristics. Meat Sci. 3, 261-265.

4. Bowling, R. A., Smith, G. C., Carpenter, Z. L., Dutson, T. R., and Oliver, W. M. (1997) Comparison of forage-finished and 
grain-finished beef carcasses. J. Anim. Sci. 45, 209-215.

5. Bozzolo, H., Bouiller, O. M., Boisseson, E., De Chasson, M., and Grasset, D. (1990) Effect of performance on characteristics of adi-pose tissue of lambs weaned early and given a concentrate high in energy. Annales de Zootechnie. 39, 7794.

6. Bruns, K. W., Pritchard, R. H., and Boggs, D. L. (2004) The relationships among body weight, body composition, and intramuscular fat content in steers. J. Anim. Sci. 82, 13151322.

7. Cho, S. H., Park, B. Y., Kim, J. H., Hwang, I. H., Kim, J. H., and Lee, J. M. (2005) Fatty acid profiles and sensory properties of Longissirnus dorsi, Triceps brachii, and semimembanosus musclls from Korean Hanwoo and Australian Angus beef. Asian-Aust. J. Anim. Sci. 18, 1786-1793.

8. CIE (1986) Colorimetry. $2^{\text {nd }}$ ed., Commision Internationale de Leclairage I'Eclairage, Publication CIE No. 15.2. Vienna.

9. Cranwell, C. D., Unruh, J. A., Brethour, J. R., and Simms, D. D. (1996) Influence of steroid on plants and concentrate feeding on carcass and longissimus muscle sensory and collagen characteristics of cull beef cows. J. Anim. Sci. 74, 1777-1783.

10. Davis, G. W., Cole, A. B., Backus, W. R. Jr., and Melton, S. L. (1981) Effect of electrical stimulation o carcass quality and meat palatability of beef from forage and grain-finished steers. J. Anim. Sci. 53, 651-657.

11. Field, R. A. (1971) Effect of castration on meat quality and quantity. J. Anim. Sci. 32, 849-858.

12. Folch, J., Lees, M., and Stanley, G. H. S. (1957) J. Biol. Chem. 226, 497-500.

13. Gotoh, T., Albrecht, E., Teuscher, F., Kawabata, K., Sakahita, K., Iwamoto, H., and Wegner, J. (2009) Differences in muscle and fat accretion in Japanese Black and European cattle. Meat Sci. 82, 300-308.

14. Honikel, K. O. (1998) Reference methods for the assessment of physical characteristics of meat. Meat Sci. 49, 447-457.

15. Heurta-Leidenz, N. O., Cross, H. R., Svell, J. W., Lunt, D. K., Baker, J. F., and Smith, S. B. (1996) Fatty acid composition of subcutaneous adipose tissue from male calves at different stages of growth. J. Anim. Sci. 74, 1256-1264.

16. Kang, S. W., Ki, K. S., Oh, Y. K., Kim, K. H., and Choi, C. W. (2005) Effects of roughage feeding type during growing and early-fattening periods on growth performance, feed efficiency and carcass characteristics in Holstein steers. Korean J. Anim. Sci. Technol. 47, 769-782.

17. Katz, L. S. (2007) Sexual behavior of domeicated ruminants. Hormonal behavior 52, 56-63.

18. Kim, D. G., Jung, K. K., Sung, S. K., Choi, C. B., Kim, S. K., Kim, D. Y., and Choi, B. J. (1996) Effects of age on the carcass characteristics of Hanwoo and Holstein steers. Agri. Sci. Lib. 38, 239-248.

19. Kim, D. G., Jung, K. K., Sung, S. K., Choi, C. B., Kim, S. K., Kim, D. Y., and Choi, B. J. (1996) Effects of age on the carcass characteristics of Hanwoo and Holstein steers. Korean J. Anim. Sci. 38, 268-274.

20. Knight, T. W., Cosgrove, G. P., Death, A. F., and Anderson,
C. B. (1999) Effect of interval from castration of bulls to slaughter on carcass characteristics and meat quality. New Zealand J. Agric. Res. 42, 269-277.

21. Korea Institute for Animal Product's Quality Evaluation (KAPE) (2011) Animal Products Grading Statistical Yearbook.

22. Kwak, B. O., Ha, J. K., and Jang, B. S. (1995) Effect of fat addition and bST injection on performance, blood serum metabolites and hormone of Hanwoo. Korean J. Anim. Sci. Technol. 37, 167-178.

23. Lunstra, D. D., Ford, J. J., and Echternakamp, S. E. (1978) Puberty in beef bulls : hormanone concentrations, growth, testicular development, sperm production and sexual aggressiveness in bulls of different breeds. J. Anim. Sci. 46, 10541062.

24. Macleod, G. (1994) The flavor of beef. In the flavor of meat and meat products, Shaidi, F. (ed), Blackie, London, pp. 437.

25. Melton, S. L. (1990) Effect of feeds on flavor of red meat : A review. J. Anim. Sci. 68, 4421-4435.

26. MIFAFF (Ministry for Food, Agriculture, Forest and Fisheries). (2011) Information and data of agricultural statistics of Korea. http://ebook.maf.go.kr/07stat (assessed July 25, 2012).

27. Moody, W. G. (1983) Beef flavor-A review. Food Technol. 37, 227-232, 238.

28. Morgan, J. R., Wheeler, T. L., Koohmaraie, M., Savell, J. W., and Crouse, J. D. (1993) Meat tenderness and the calpain proteolytic system in longissims muscle of young bulls and steers. J. Anim. Sci. 71, 1471-1476.

29. Morrison, W. R. and Smith, L. M. (1964) Preparation of fatty acid methylesters and dimethylacetals from lipid with boron fluoridemethanol. J. Lipid Res. 5, 600-608.

30. National Livestock Cooperatives Federation (NLCF) (1998). Korean carcass grading standard. Seoul: National Livestock Cooperatives Federation.

31. Li, L.Q., Tian, W. Q., and Zan, K. S. (2011) Effects of age on quality of beef from Qinchuan cattle carcass. Agric. Sci. (China). 10, 1765-1771.

32. Perry, D., Nichols, P. J., and Thomson, J. M. (1998) The effect of sire breed on the melting point and fatty acid composition of sub-cutaneous fat in steers. J. Anim. Sci. 76, 8795.

33. Pethick, D. W., Harper, G. S., and Oddy, V. H. (2004) Growth, development and nutritional manipulation of marbling in cattle: A review. Australian J. Exp. Agric. 44, 705-715.

34. Platter, W. J., Tatum, J. D., Belk, K. E., Koontz, S. R., Chapman, P. L., and Smith, G. C. (2005) Effects of marbling and shear force on consumers' willingness to pay for beef strip loin steaks. J. Anim. Sci. 83, 890-899.

35. Purchas, R. W., O'Brien, L. E., and Pendleton, C. M. (1979) Some effects of nutrition and castration on meat production from male Suffolk cross (Border Leicester-Romney cross) lambs. New Zealand J. Agric. Res. 22, 375-395.

36. Purchas, R. W., Burnham, D. L., and Morris, S. T. (2002) Effects of growth potential and growth path on tenderness of beef longissimus muscle from bulls and steers. J. Anim. Sci. 
80, 3211-3221.

37. Raes, K., Haak, L., Balcaen, A., Claeys, E., Demeyer, D., and De Smet, S. (2004) Effect of linseed feeding at similar linoleic acid levels on the fatty acid composition of doublemuscled Belgian Blue young bull. Meat Sci. 66, 307-315.

38. Risvik, E. (1994) Sensory properties and perference. Meat Sci. 36, 67-77.

39. Robelin, J. (1986) Growth of adipose tissues in cattle; partitionning between depots, chemical composition and cellularity. A review. Livest. Prod. Sci. 14, 349-364.

40. Ryoichi, S., Degychi, T., and Nagata, Y. (1993) Effectiveness of the filter paper press methods for determining the water holding capacity of meat. Fleichwirtsch 73, 1399.

41. SAS (2005) SAS/STAT Software for PC. Release 6.11, SAS Institute Inc., Cary, NC, USA.

42. Scollan, N. D., Choi, N. J., Kurt, E., Fisher, A. V., Enser, M., and Wood, J. D. (2001) Manipulating the fatty acid composition of muscle and adipose tissue in beef cattle. British $J$. Nutr. 85, 115-124.
43. Sung, S. K., Jung K. K., Choi, C. B., Kim, D. G., Kim, S. G., Kim, D. Y., and Choi, B. J. (1996) Effects of castration and age on the carcass composition and retail yields of Hanwoo and Holstein. Korean J. Anim. Sci. Technol. 38, 261-267.

44. Turek, J. J., Schoenlein, I. A., Watkins, B. A., Vanalstine, W. G., Clark, L. K., and Knox, K. (1996) Dietary polyunsaturated fatty acids modulate responses of pigs to mycoplasmahyopneumoniae infection. J. Nutr. 126, 1541-1548.

45. Wheeler, T. L., Shackelford, S. D., and Koohmaraie. M. (2000) Variaton in proteolysis, sarcomere length, collagen content, and tenderness among major pork muscles. J. Anim. Sci. 78, 958-965.

46. Zhang, J. J., Sasaki, S., Amano, K., and Kesteloot, H. (1999) Fish consumption and mortality from all causes, ischemic heart disease, and stroke: an ecological study. Preventive Medicine. 28, 520-529.

(Received 2012.9.17/Revised 2012.10.16/Accepted 2012.11.12) 